\title{
Histopathology of the thymus of coho salmon Oncorhynchus kisutch experimentally infected with Renibacterium salmoninarum
}

\author{
E. Flaño ${ }^{1}$, S. L. Kaattari ${ }^{2}$, B. Razquin ${ }^{1}$, A. J. Villena ${ }^{1, *}$ \\ ${ }^{1}$ Departamento de Biología Celular y Anatomía, Facultad de Biología, Universidad de León, E-24071 León, Spain \\ ${ }^{2}$ Virginia Institute of Marine Science, The College of William \& Mary, Gloucester Point, Virginia 23062-1346, USA
}

\begin{abstract}
We report on the histopathological changes occurring in the thymus of coho salmon Oncorhynchus kisutch experimentally infected with Renibacterium salmoninarum. Coho salmon were intraperitoneally infected, and the thymi were collected weekly from 1 to $7 \mathrm{wk}$ post-infection, and processed for ultrastructural study. The thymus appeared to be infected only in tish collected at 6 and $7 \mathrm{wk}$ post-infection. The first stage of the infection was characterized by the presence of a low number of bacteria scattered in the connective tissue of the capsule. Further progression of the thymic infection was characterized by the rupture of the capsular-thymic barrier, and by the bacterial colonization of the subcapsular and inner zones of the parenchyma, where the bacteria were located mainly in macrophages, but also apparently in pale reticular-epithelial cells and in thymocytes. Other reticularepithelial cells, and the vascular trabeculae, remained free of $R$. salmoninarum during the initial stages of the infection. In severely infected thymi, necrosis of the parenchyma of the subcapsular and inner zones, and bacterial invasion of the trabeculae occurred. The integrity of the pharyngeal epithelium covering the thymus was not affected during the infection.
\end{abstract}

KEY WORDS: BKD - Renibactenum salmoninarum - Histopathology Thymus - Oncorhynchus kisutch . Fish

\section{INTRODUCTION}

Bacterial kidney disease $(B K D)$ is a chronic systemic disease, caused by the Gram-positive bacterium Renibacterium salmoninarum (Sanders \& Fryer 1980, Fryer \& Sanders 1981, Austin \& Austin 1993, Evenden et al. 1993, Fryer \& Lannan 1993). BKD is characterized by a granulomatous inflammatory response (Wolke 1975), and shows a marked affinity for kidney tissue (Belding \& Merril 1935, Earp et al. 1953). Histopathological studies have demonstrated that natural and experimental infections with $R$. salmoninarum result in granulomas in the kidney, spleen, liver, and muscle (Wood \& Yasutake 1956, Bruno 1986), and glomerulonephritis (Young \& Chapman 1978, Sami et al. 1992). Also the brain, gills, and the circulatory system are affected (Wood \& Yasutake 1956), and the disease

\footnotetext{
-Addressee for correspondence. E-mail: villena@ibm.net
}

causes anaemia and destruction of the haematopoietic tissue (Wood \& Yasutake 1956).

Renibacterium salmoninarum is considered to be an obligate pathogen (Evenden et al. 1993), and different studies indicate that this is an intracellular pathogen, which is able to survive and multiply intracellularly in host macrophages (Young \& Chapman 1978, Bruno, 1986, Bandín et al. 1993). Due to the intracellular location of $R$. salmoninarum it is assumed that a major part of the fish defensive response is played by cell-mediated immune mechanisms (Evenden et al. 1993, Sakai et al. 1993). Several studies have demonstrated that fish suffering natural and experimental infections or vaccinated against $B K D$ are able to mount a specific, but low humoral immune response against $R$. salmoninarum (Paterson et al. 1981, Bruno 1987, Kaattari et al. 1989, Sakai et al. 1993). The lack of protective immunity after vaccination or natural infection (Elliot et al. 1989, Sakai et al. 1993) has been correlated with immunosuppression produced by $R$. salmoninarum 
products, such as the p57 antigen (Evenden et al. 1993). This immunosuppresion affects the cellular and humoral immune responses (Turaga et al. 1987, Evenden et al. 1993), as well as other non-specific defence mechanisms, including the activation of macrophages (Sakai et al. 1991)

The thymus of fish is considered to be the equivalent of the mammalian thymus, and is involved in the maturation of T-cells (Ellsaesser et al. 1988, Chilmonczyk 1992). Although fish T-cells are poorly phenotypically and functionally characterized (Chilmonczyk 1992), they probably mediate T-cell functions in fish, such as graft rejection, mixed lymphocyte reaction, helper function, delayed hypersensitivity, and lymphokine production (Clem et al. 1991, Chilmonczyk 1992). Thus, T-cell functions may be of importance in the host response to Renibacterium salmoninarum, either directly via T-helper or T-cytotoxic/suppressor cells, or via various cytokines which, in mammals, regulate many different aspects of the immune response to intracellular parasites (Reed \& Scott 1993). Similar cellular (Clem et al. 1991) and cytokine-mediated (Secombes 1991) mechanisms are present in fish.

In spite of a number of immunological and histopathological studies on $\mathrm{BKD}$, no attention has been paid to the thymus in natural or experimentally infected fish. In this work we describe the ultrastructural changes occurring in the thymus of coho salmon Oncorhynchus kisutch experimentally infected with Renibacterium salmoninarum. The study is part of a larger one the structural and functional alterations produced by BKD in the lymphoid organs (Villena et al. 1989, Flaño et al. 1996).

\section{MATERIAL AND METHODS}

Salmon. Fingerling ( 6 to $8 \mathrm{~cm}$ in length) coho salmon were kept in $1 \mathrm{~m}^{3}$ circular tanks supplied with $12^{\circ} \mathrm{C}$, pathogen-free flow-through well water under natural photoperiod conditions, and fed daily with Oregon Moist Pellets (Bioproducts, Warrington, OR, USA) at the Oregon State University Salmon Disease Laboratory (Corvallis, OR).

Experimental infection. Infected fish were held in 130 l tanks supplied with flow-through water from the same source as described above. Thirty salmon (10 fish per tank) were injected with a single dose of $0.1 \mathrm{ml}$ $\left(O D_{500}: 1.0\right)$ of a broth culture of Renibacterium salmoninarum D6 isolate (C. Banner) in saline. Ten noninfected salmon, maintained in the same conditions as described above, were used as controls. Fish were sampled at $1,2,3,4,5,6$, and $7 \mathrm{wk}$ post-infection (w.p.i.) for routine histology techniques. For the electron microscopy study, samples were taken at 2, 6, and
7 w.p.i. At each sampling, 3 infected and 1 control salmon were euthanized by anaesthetic overdose using a $200 \mathrm{mg} \mathrm{I}^{-1}$ solution of MS-222 (Sandoz). The fish were then bled by severing the tail and the thymi were aseptically removed.

To confirm the identity of the bacterium in the tissues of the challenged fish, sampled tissues (cryostat sections of kidney, spleen, thymus, and liver) were examined by the indirect immunoperoxidase technique (Graham \& Karnovsky 1966), using a monoclonal antibody ( $3 \mathrm{H} 1$ ) specific for the $\mathrm{p} 57$ protein of this pathogen (Wiens \& Kaattari 1991)

Electron microscopy. Small pieces of the thymi were fixed for $4 \mathrm{~h}$ in $2 \%$ glutaraldehyde in cacodylate buffer, $0.1 \mathrm{M}, \mathrm{pH} 7.2$, at $4^{\circ} \mathrm{C}$. Tissues were then postfixed at $4^{\circ} \mathrm{C}$ for $1 \mathrm{~h}$ in $1 \%$ osmium tetroxide in the same buffer, dehydrated in acetone, and embedded in Araldite (Durcupan). Semithin ( $1 \mu \mathrm{m}$ thick) and ultrathin sections were cut on a Reichert UM-3 ultratome with glass knives. Semithin sections were stained with a $1 \%$ aqueous solution of toluidine blue in borax. Ultrathin sections were transferred to copper grids, stained with uranyl acetate and lead citrate (Reynolds 1963) and observed in a Jeol-100C electron microscope at $80 \mathrm{kV}$.

\section{RESULTS}

The progression of the infection was documented by the appearance of external signs of the disease (swollen abdomen, and in some cases moderate exophthalmia) and the presence of internal lesions, which included granulomatous lesions in the kidney, liver, and spleen, and also in some fish the presence of a pseudomembrane covering these organs. The histopathological changes occurring in the kidney and spleen have been described elsewhere (Flaño et al. 1996). Renibacterium salmoninarum was considered to be the causative agent of the infection in the challenged fish, as the kidney, spleen, liver, and thymus contained Gram-positive rods, which were stained with the $3 \mathrm{H} 1$ monoclonal antibody anti-p57 protein (Villena et al. 1989).

The anatomical location and structure of the thymus in the control coho salmon was similar to that described for this organ in rainbow trout (Chilmonczyk 1983, Castillo et al. 1990). The thymus was delimited by a connective capsule (Fig. 1A), and the parenchyma consisted of 3 different regions (Fig. 1A): (1) a subcapsular area, which contained thymoblasts, limiting reticular-epithelial cells apposed to the basal membrane of the capsule, and large subcapsular reticularepithelial cells; (2) an inner zone, containing dense populations of small thymocytes arranged in a matrix 


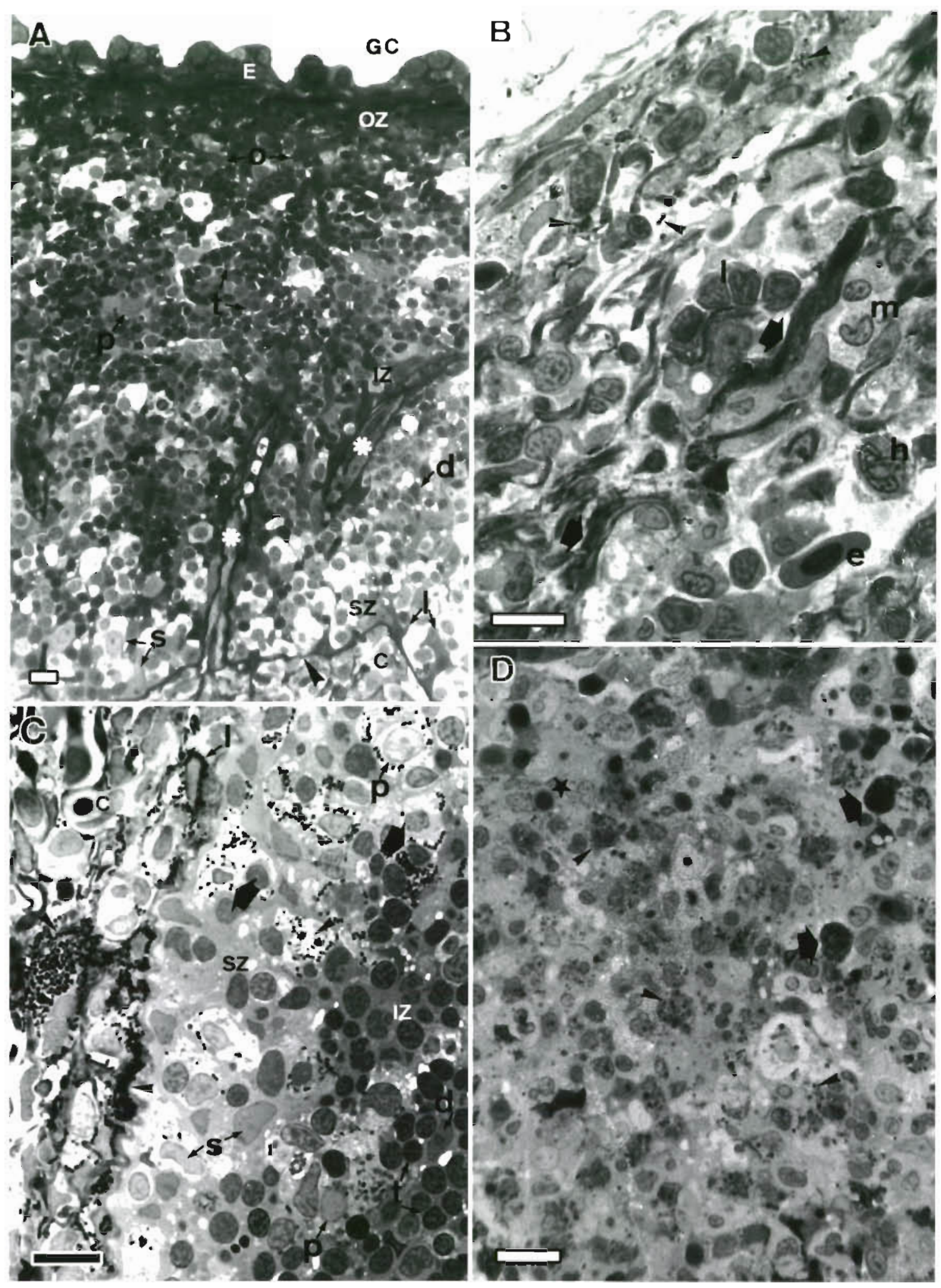

Fig. 1. Histology of the thymus in normal (control) and Renibacterium salmoninarum-infected coho salmon Oncorhynchus kisutch. (A) Control thymus. C: capsule; arrowhead: basal membrane; SZ: subcapsular zone; IZ: inner zone; OZ: outer zone; E: pharyngeal epithelium; asterisk: trabeculae; l: limiting reticular-epithelial cells; s: subcapsular reticular-epithelial cells; p: pale reticular-epithelial cells; $d$ : dark reticular-epithelial cells; o: reticular-epithelial cells of the outer zone; t: thymocytes. GC: gill chamber. (B) Connective tissue capsule of the thymus with a low number of bacteria (arrowheads) at 6 w.p.i. l: lymphocyte; h: heterophile; m: monocyte; e: erythrocyte; thick arrows: connective fibres. (C) Infected thymus at 6 w.p.i. The capsule (C), subcapsular (SZ) and inner zones (IZ) are shown. Note the presence of bacteria in macrophages (thick arrows), limiting reticularepithelial cells (1), and some pale reticular-epithelial cells (p). s: subcapsular reticular-epithelial cells; d: dark reticular-epithelial cells; t: thymocytes; arrowhead: bacteria. (D) Heavily infected thymus at 7 w.p.i. showing necrosis of the parenchyma. Thick arrows: infected macrophage; star: pyknotic cells; arrowheads: bacteria. Semithin sections. Scale bars $=10 \mu \mathrm{m}$ 
of dark reticular-epithelial cells, and ovoid pale reticuIar-epithelial cells; and (3) an outer zone, externally limited by the pharyngeal epithelium, which contained a low number of thymocytes and densely arranged reticular-epithelial cells. The thymic parenchyma was traversed by vascular trabeculae running from the capsule (Fig. 1A), which were delimited by peritrabecular reticular-epithelial cells, and contained blood vessels surrounded by loose connective tissue.

The thymi appeared infected only in fish collected at 6 and 7 w.p.i., at which stage most of the fish showed severe internal lesions, including haemorrhages and renal liquefaction. No infected fish survived over 7 w.p.i. In the thymus, the first stage of the infection. was characterized by the presence of a low number of scattered bacteria located in the connective tissue of the capsule (Fig. 1B), which was highly colonized by lymphoid cells, monocytes, and heterophiles, and showed haemorrhages (Fig, 1B). Further progression of the thymic infection was characterized by an increase in the number of bacteria in the capsule, and presence of bacteria in the subcapsular and inner zones of the parenchyma (Fig. 1C). In the capsule, masses of bacteria occurred in association with the basal membrane, which forms part of the capsularthymic barrier (Fig. 1C). Most bacteria in the capsule were located extracellularly (Fig, 2A), but fibroblasts also appeared to be invaded by Renibacterium salmoninarum (Fig. 2A). The necrosis of the connective tissue was accompanied by the disruption of the collagen fibres and of the basal membrane (Fig. 2A), and necrosis of the limiting reticular-epithelial cells (Fig. 2B).

In the parenchyma, bacteria were located mainly in the cytoplasm of macrophages (Figs, 1C, 2C \& $3 \mathrm{~A}$ ), some of which appeared lysed (Figs, 2C \& 3A). Often, the macrophages contained large cell debris, possibly of host-cell origin (Fig. 3A). The bacteria aiso appeared frequently colonizing the cytoplasm of pale reticularepithelial cells (Fig. 3B), while most peritrabecular, dark reticular-epithelial cells (Fig. 3C) and those of the outer zone (Fig. 2C) were free of Renibacterium salmoninarum. Most trabeculae were also free of bacteria (Fig. 3C). Some thymocytes, mainly those located near other heavily infected cell types, contained a large number of bacteria and appeared lysed (Figs. 2C \& $3 B, C)$. The integrity of the pharyngeal epithelium covering the thymus was not affected during the infection, and although bacteria were present in the branchial cavity, they did not invade the epithelium (Fig. 2C).

In the more heavily infected thymi, the number of bacteria increased in the subcapsular and inner thymic zones, and disorganization and necrosis of these zones (Fig. 1D), which contained numerous pyknotic cells and macrophages with large residual bodies, also occurred. At this stage, most cells in the parenchyma appeared to be infected, and bacteria colonized the vascular trabeculae (Fig. 3D).

\section{DISCUSSION}

Four to 5 wk after experimental infection with Renibacterium salmoninarum, most inner organs were invaded by the pathogen (Flaño et al. 1996). However, infection of the thymus occurred more slowly. Thus, the thymus appeared infected only after the pathogen had spread throughout most of the other tissues. The major route of entry of bacteria into the thymus seemed to occur via the connective tissue of the capsule. Although bacteremia has been reported to be the main route by which tissues become infected (Wood \& Yasutake 1956, Young \& Chapman 1978, Speare et al. 1993), we did not observe bacteria in the thymic blood vessels until the parenchyma was completely necrotic. This may be due to the specific organization of the thymic vascularization, which comprises a continuous endothelium and basal membrane, and is surrounded by the peritrabecular reticularepithelial cells that form the so-called blood-thymic barrier (Zapata 1981, Castillo et al. 1991, Chilmonczyk 1992). The presence of a similar anatomical barrier in the brain (the blood-brain barrier) has been implicated also in the relative protection of the brain parenchyma against colonization by $R$. salmoninarum (Speare et al. 1993).

The pharyngeal epithelium covering the thymus, the only barrier separating the external environment from the thymic parenchyma, seemed to be impenetrable to Renibacterium salmoninarum. In several samples, bacteria could be observed in the gill chamber, closely apposed to the pharyngeal epithelium, but no bacteria were found invading this epithelium. The origin of such bacteria is uncertain, but it may be from the water contaminated with faeces released by the infected fish (Mitchum \& Sherman 1981), or from external haemorrhages of the infected gills.

The relative resistance of the thymus to the infection might be explained by the transcapsular route followed by Renibacterium salmoninarum. Invasion of the thymic parenchyma occurred only after the thymic capsule was breached. Disruption of the capsular barrier occurred only in areas where the extracellular bacteria were closely apposed to the barrier's components (i.e. the thymic basal membrane and the limiting reticular-epithelial cells). This suggests that $R$. salmoninarum is able to release 'short-range' extracellular products, capable of digesting both the extracellular matrix of the connective tissue and the thymic 


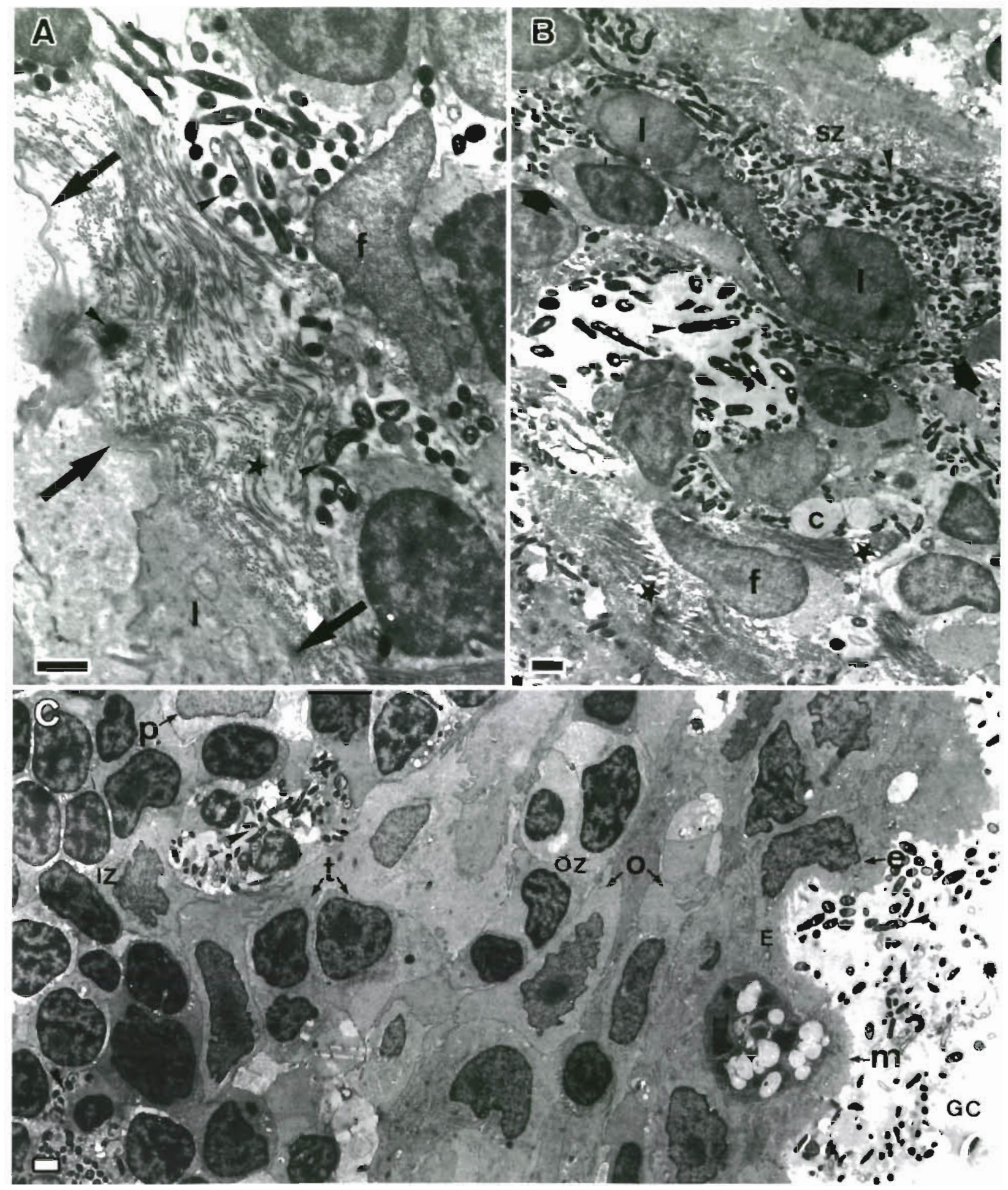

Fig. 2. Ultrastructure of the thymus in Renibacterium salmoninarum-infected coho salmon Oncorhynchus kisutch at 6 w.p.i. (A) Micrograph showing the disorganization of the thymic capsule close to the basal membrane (arrows). 1: limiting reticularepithelial cell; f: fibroblast; star: connective fibres; arrowheads: bacteria. (B) Micrograph showing the capsule (C) and subcapsular zone (SZ). Note the discontinuities of the capsular-thymic barrier (thick arrows), in which bacteria appear. l: limiting reticular-epithelial cells in a necrotic state; f: fibroblast; star: connective fibres; arrowheads: bacteria. (C) Low power view of the inner (IZ) and outer (OZ) zones, and of the pharyngeal epithelium (E). Note the presence of bacteria in the gill chamber (GC). e: pharyngeal epithelial cell; $\mathrm{m}$ : mucous cell; $\mathrm{o}$ : reticular-epithelial cells of the outer zone; $\mathrm{p}$; pale reticular-epithelial cell; $t$ : thymocyte; arrowhead: bacteria. Scale bars $=1 \mu \mathrm{m}$ 


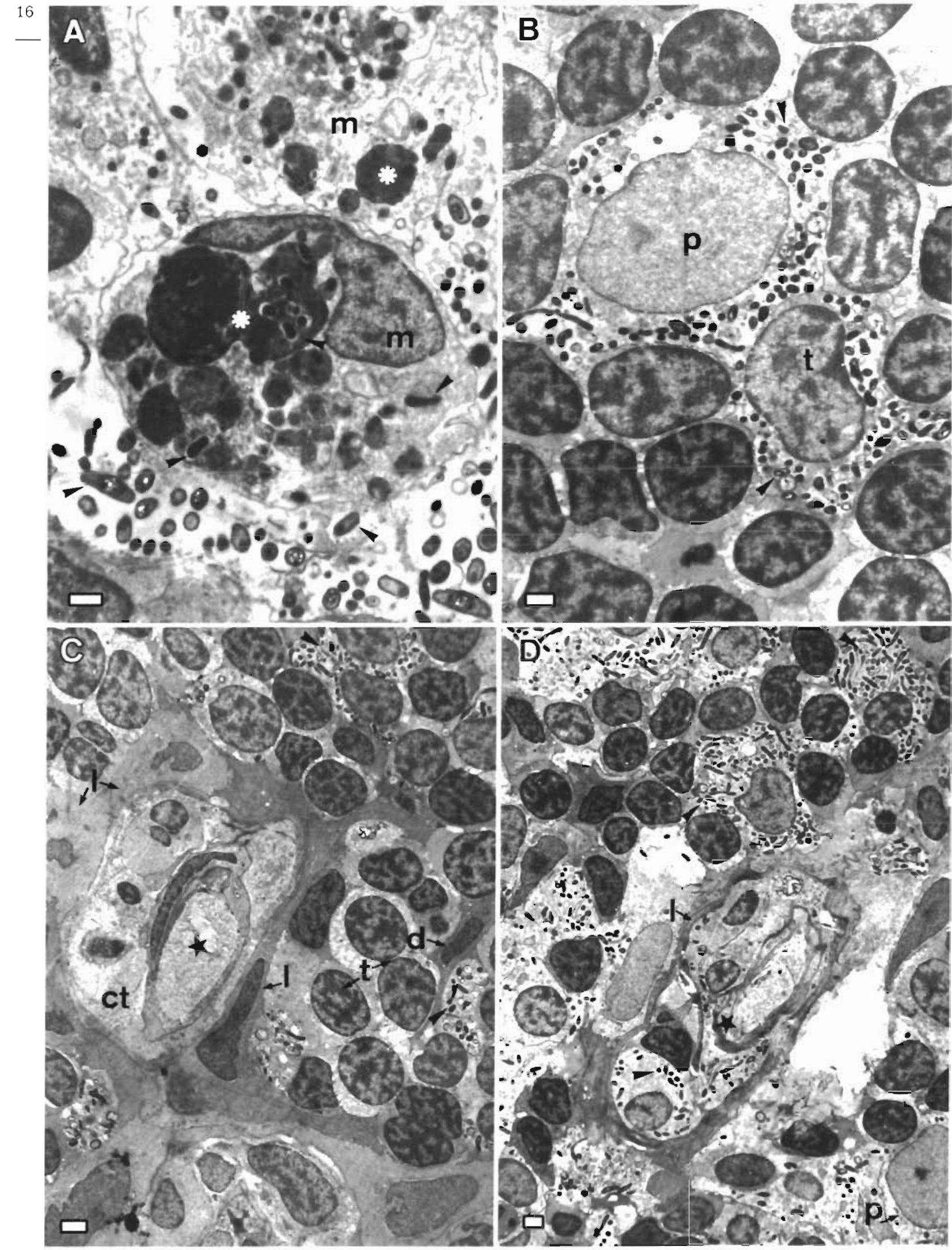

Fig. 3. Ultrastructure of the thymus in Renibacterium salmoninarum-infected coho salmon Oncorhynchus kisutch. (A) Infected and lysed macrophages ( $\mathrm{m}$ ) containing bacteria (arrowheads) and phagosomes (asterisks). 6 w.p.i. (B) Pale reticular-epithelial cell (p) and thymocyte (t) with bacteria (arrowheads), 6 w.p.i. (C) Low power view of the inner zone showing a trabecula with a blood vessel (star) surrounded by loose connective tissue (ct), and by peritrabecular reticular-epithelial cells (l). 6 w. p.i. d: dark reticularepithelial cells; t: thymocytes; arrowheads: bacteria. (D) Heavily infected inner zone with a trabecula (star) containing bacteria 7 w.p.i. l: peritrabecular reticular-epithelial cells; p: pale reticular-epithelial cell; arrowheads: bacteria. Scale bars $=1 \mu \mathrm{m}$ 
basal membrane. The production of such products by the bacterium is suggested by the strong proteolytic activity found in BKD lesions (Sakai et al. 1989).

The presence of bacteria in the connective tissue of the thymic capsule was accompanied by its infiltration by numerous lymphoid cells (monocyte-macrophages and heterophiles), suggesting the existence of a local inflammatory reaction such as has been described in natural and experimental infections (Villena et al. 1989, Evenden et al. 1993). This response might also have contributed to the infection of the thymic parenchyma via migrating Renibacterium salmoninaruminfected macrophages. This source of thymic infection was suggested by the presence of thymic macrophages containing bacteria during the earlier stages of the infection. The macrophages, which initially accumulated in the capsule, may have been infected there by $R$. salmoninarum, and then migrated into the organ carrying the intracellular viable bacterium, as they have been shown to do in other tissues (Young \& Chapman 1978, Bruno 1986, Evenden et al. 1993).

After the entry of Renibacterium salmoninarum into the thymic parenchyma, it appeared to invade the reticular-epithelial cells and perhaps also the thymocytes. The pale reticular-epithelial cells of the inner zone appeared to be particularly susceptible to the infection, as they were frequently degenerate and invaded by $R$. salmoninarum. In the final stages of the infection, however, all types of reticular-epithelial cells appeared to be degenerate, lysed, or invaded by bacteria. Also, bacteria appeared in the cytoplasm of many thymocytes, most of which appeared to be lysed. Unfortunately, our structural study did not permit firm conclusions on whether the bacteria in the cytoplasms of the reticular-cells and thymocytes represented a specific capacity of $R$. salmoninarum to infect them. Due to the narrowness of the intercellular spaces in the thymic parenchyma, it was not usually possible to observe the cell membranes for their intactness. It is possible, therefore, that the bacterium merely invaded the cytoplasm of previously lysed cells. Cell lysis might have been mediated by the putative membrane damaging factor released by or attached to the bacterial surface (Evenden et al. 1993).

The functional significance of the thymic infection by Renibacterium salmoninarum in this study is uncertain because the model studied involved an acute and lethal experimentally induced infection that resulted in the total necrosis of the thymus. More information on the significance of thymic infectinos might be forthcoming from subacute $R$. salmoninarum infections. Hypothetically, if the pathogen or its products manage to enter the thymus of fish with subacute or chronic infections, this might result in immunosuppression (Turaga et al. 1987, Evenden et al. 1993) and might contribute to the lack of an effective immunological response to $R$. salmoninarum such as has been noted by various workers (Evelyn et al. 1988, Munro \& Bruno 1988). Further studies on the thymic pathology in BKD are needed, especially in natural or in subacute experimental infections, to elucidate this point.

Acknowledgements. We thank Dr Prasad Turaga for conducting the experimental infection. This research was funded in part by the Spanish CYCYT, grant MAR91-0851. Cooperation between the University of León and Oregon State University was funded by grants from the DGICYT (Spanish Ministry of Education and Science) for 'Perfeccionamiento del Profesorado' awarded to Dr Razquin and Dr Villena. E. Flaño was supported by EC contract AIR1 CT920036.

\section{LITERATURE CITED}

Austin B, Austin DA (1993) Aerobic Gram-positive rods and cocci excluding the lactobacilli. In: Laird LM (ed) Bacterial fish pathogens. Disease in farmed and wild fish, 2nd edn. Ellis Horwood Ltd, Chichester, p 43-85

Bandín I. Ellis AE, Barja JL, Secombes CJ (1993) Interaction between rainbow trout macrophages and Renibacterium salmoninarum in vitro. Fish Shellfish Immunol 3:25-53

Belding DL, Merril B (1935) A preliminary report upon a hatchery disease of the Salmonidae. Trans Am Fish Soc 65:135-137

Bruno DW (1986) Histopathology of bacterial kidney disease in laboratory infected rainbow trout, Salmo gairdneri Richardson, and Atlantic salmon, Salmo salar L., with reference to naturally infected fish. J Fish Dis 9:523-537

Bruno DW (1987) Serum agglutinating titres against Renibacterium salmoninarum the causative agent of bacterial kidney disease, in rainbow trout, Salmo gairdneri Richardson, and Atlantic salmon, Salmo salar L. J Fish Biol 30: $327-334$

Castillo A, López-Fierro P, Alvarez F, Zapata A, Villena A. Rezquin B (1991) Post-hatching development of the thymic epithelial cells in the rainbow Salmo gairdneri: an ultrastructural study. Am J Anat 190:299-307

Castillo A, Razquin B, López-Fierro P, Alvarez F, Zapata A. Villena A (1990) Enzyme and immuno-histochemical study of the thymic stroma in the rainbow trout, Salmo gairdneri Rich. Thymus 15:153-166

Chilmonczyk $S$ (1983) The thymus of the rainbow trout (Salmo gairdneri). Light and electron microscopic study. Dev Comp Immunol 7:59-68

Chilmonczyk S (1992) The thymus in fish: development and possible function in the immune response. A Rev Fish Dis 2: $181-200$

Clem LW, Miller NW, Bly JE (1991) Evolution of lymphocyte subpopulations, their interactions and temperature sensitivities. In: Warr GW, Cohen N (eds) Phylogenesis of immune functions. CRC Press Inc, Boca Raton, FL, p 191-213

Earp BJ, Ellis $\mathrm{CH}$, Ordal EJ (1953) Kidney disease in young salmon. Washington, Department of Fisheries, Spec Rep $1: 1-74$

Elliot DG, Pascho RJ, Bullock GL (1989) Developments in the control of bacterial kidney disease of salmonid fishes. Dis Aquat Org 6:201-215

Ellsaesser CF, Bly JE, Clem LW (1988) Phylogeny of lympho- 
cyte heterogeneity. The thymus of the channel cat fish. Dev Comp Immunol 12:787-799

Evelyn TPT, Ketcheson JE, Prosperi-Porta L (1988) Trials with anti-bacterial kidney disease vaccines in two species of Pacific salmon. International Fish Health Conference, Vancouver, B.C., Canada. Fish Health Section, American Fisheries Society, Washington, DC, p 38

Evenden AJ, Grayson TH, Gilpin ML, Munn CB (1993) Renibacterium salmoninarum and Bacterial Kidney Disease-The unfinished jigsaw. A Rev Fish Dis 3:87-104

Flaño E, López-Fierro P, Razquin B, Kaattari SL, Villena A (1996) Histopathology of the renal and splenic haemopoietic tissues of coho salmon Oncorhynchus kisutch experimentally infected with Renibacterium salmoninarum. Dis Aquat Org 24:107-115

Fryer JL, Lannan CN (1993) The history and current status of Renibacterium salmoninarum, the causative agent of bacterial kidney disease in Pacific salmon. Fish Res 17: $15-33$

Fryer JL, Sanders JE (1981) Bacterial kiủney disease of salmonid fish. A Rev Microbiol 35:273-298

Graham RC Jr, Karvnosky MJ (1966) The early stages of adsorption of injected horseradish peroxidase in the proximal tubules of mouse kidney: ultrastructural cytochemistry by a new technique. J Histochem Cytochem 14: $291-302$

Kaattari SL, Turaga P, Villena A, Razquin B (1989) Formation of anti-Renibacterium salmoninarum immune complexes during Bacterial Kidney Disease. International Fish Health Conference, Annapolis, Maryland, USA. Fish Health Section, American Fisheries Society, Washington, DC

Mitchum DL, Sherman LE (1981) Transmission of bacterial kidney disease from wild to stocked hatchery trout. Can J Fish Aquat Sci 38:547-551

Munro ALS, Bruno DW (1988) Vaccination against bacterial kidney disease. In: Ellis A.E (ed) Fish vaccination. Academic Press, London, p 124-134

Paterson WD, Lall SP, Desautels D (1981) Studies on bacterial kidney disease in Atlantic salmon (Salmo salar) in Canada. Fish Pathol 15:283-29

Reed SG, Scott P (1993) T-cell and cytokine responses in leishmaniasis. Curr Opin Immunol 5:524-531

Reynolds ES (1963) The use of lead citrate at high pH as an electron opaque stain in electron microscopy. Stain Technol 35:313-323

Sakai M, Atsuta S, Kobayashi M (1993) The immune response of rainbow trout (Oncorhynchus mykiss) injected with five Renibacterium salmoninarum bacterins. Aquaculture $113: 11-18$

Responsible Subject Editor: T. Evelyn, Nanaimo, British Columbia, Canada
Sakai M, Konishi M, Atsuta S, Kobayashi M (1991) The chemiluminiscent response of leukocytes from the anterior kidney of rainbow trout, Oncorhynchus mykiss vaccinated with Vibrio anguillarum, Streptococcus sp., or Renibacterium salmoninarum. Nippon Suisan GaKK 57(2):237-241

Sakai M, Ogasawara K, Atsuta S, Kobayashi M (1989) Comparative sensivity of carp, Cyprinus carpio L. and rainbow trout, Salmo gairdneri Richardson, to Renibacterium salmoninarum. J Fish Dis 12:367-372

Sami S, Fischer-Scherl T, Hoffmann RW, Pfeil-Putzien C (1992) Immune-complex mediated glomerulonephritis associated with bacterial kidney disease in the rainbow trout (Oncorhynchus mykiss). Vet Pathol 29:169-174

Sanders JE, Fryer JL (1980) Renibacterium salmoninarum gen. nov., the causative agent of bacterial kidney disease in salmonid fishes. Int J Syst Bacteriol 30:496-502

Secombes CJ (1991) The phylogeny of cytokines. In: Thomson AW (ed) The cytokine handbook. Academic Press, London, p 387-412

Speare D j, Ostiand VE, Ferguson HW (1993) Pathology associated with meningoencephalitis during bacterial kidney disease of salmonids. Res Vet Sci 54:25-31

Turaga PST, Wiens GD, Kaattari SL (1987) Bacterial kidney disease: the potential role of soluble protein antigen(s). J Fish Biol 31:191-194

Villena A, Razquin B, Turaga P, Kaattari S (1989) Role of specific immune complexes in bacterial kidney disease: an immuno- and enzyme-histochemical study on Renibacterium salmoninarum-infected coho salmon, Oncorhynchus kisutch. In: Conference handbook. Eur Assoc Fish Pathol IVth International Conference 'Diseases of Fish and Shellfish', Santiago de Compostela, Spain. Servicio de Publicaciones e Intercambio Cientifico. Universidad de Santiago de Compostela, p 180

Wiens GD, Kaattari SL (1991) Monoclonal antibody characterization of a leukoagglutinin produced by Renibacterium salmoninarum. Infect Immun 59:631-637

Wolke RE (1975) Pathology of bacterial and fungal disease affecting fish. In: Ribelin WE, Migaki G (eds) The pathology of fishes. University of Wisconsin, Madison, p 76-78

Wood EM, Yasutake WT (1956) Histopathology of kidney disease in fish. Am J Pathol 32:845-857

Young CL, Chapman GB (1978) Ultrastructural aspects of the causative agent and renal histopathology of bacterial kidney disease of brook trout (Salvelinus fontinalis). J Fish Res Bd Can 35:1234-1248

Zapata A (1981) Lymphoid organs of teleost fish. I. Ultrastructure of the thymus of Rutilus rutilus. Dev Comp Immunol $5: 427-436$

Manuscript first received: April 6, 1995

Revised version accepted: January 4, 1996 